\title{
Handbook \\ for State Energy \\ Emergency Planning
}
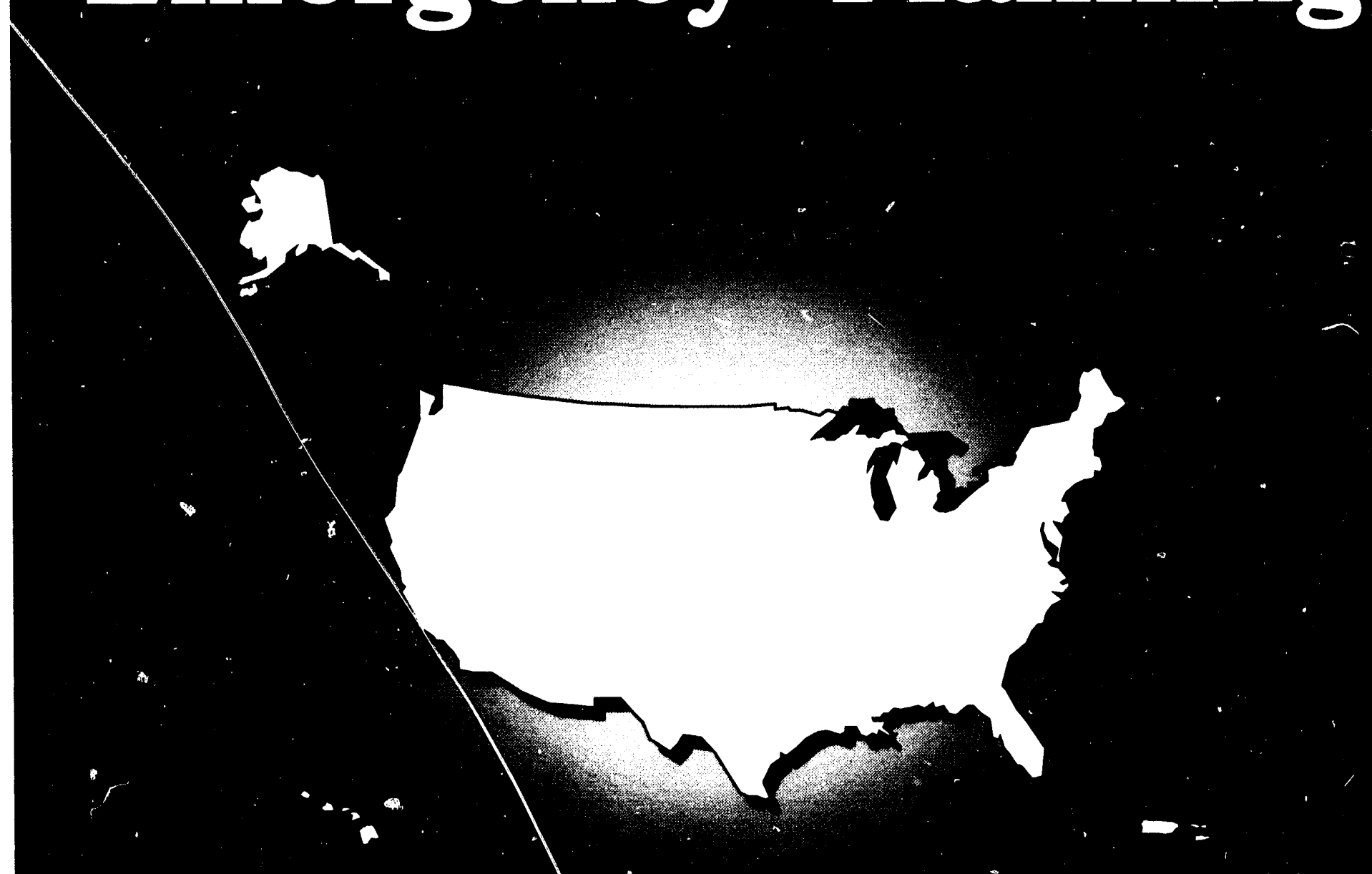

U.S. Department of Energy

Office of Energy Emergencies

Oak Ridge National Laboratory 
This report has been reproduced directly from the best available copy.

Available to DOE and DOE contractors from the Office of Scientific and Technical Information, P.O. Box 62, Oak Ridge, TN 37831 ; prices available from (615) 576-8401, FTS 626-8401.

Avallable to the public from the National Technical Information Service, U.S. Department of Commerce, 5285 Port Royal Rd., Springfield, VA 22161.

This report was prepared as an account of work sponsored by an agency of the United States Government. Neither the United States Government nor any agency thereof, nor any of their employees, makes any warranty, express or implied, or assumes any legal liability or responsibility for the accuracy, completenese, or usefulness of any information, apparatus, product, or process dieclosed, or represents that its use would not infringe privately owned rights. Reference herein to any specific commercial product, process, or service by trade name, trademark, manufacturer, or otherwise, does not necessarily constitute or imply its endorsement, recommendation, or favoring by the United States Government or any apency thereof. The views and opinions of authors expressed herein do not necessarily state or reflect those of the United States Government or any agency thereof. 
ORNL- -6681

DE92 000403

\section{HANDBOOK}

\section{FOR STÁte ENERGY}

\section{Emergency Planning}

DATE PUBLISHED： SEPTEMBER 1991

U.S. Department of Energy Office of Energy Emergencies

Oak Ridge National Laboratory

December 1990 


\section{Introduction}

This document' presents some basic ideas about developing plans for dealing with energy shortages and contains a range of topics and considerations that state government officials and planners may wish to review in formulating an energy emergency plan. Those states in advanced stages of plan development might wish to use this document as a means of reviewing their plans or for possible revisions or refinements.

It is impossible to develop a single model emergency plan generally applicable to a! states. Because potential emergency problems and response capabilities differ substantially among states, plans must be tailored to individual state or regional needs. Thus, this document introduces a number of key factors and options from which states may choose when finalizing their energy emergency plans. No state should feel bound to include all or even any of the suggestions in this report. For some states, the report can serve as a road map to formulate a plan from scratch; for others, it can serve as a checklist to ensure that all relevant issues have been addressed. In any case, the report is intended to serve as a vehicle for improving planning efforts and does not seek to provide criteria by which to judge or compare different states' plans.

There are six basic steps to the planning format presented in this report. These steps, and additional items that logically fall under them, are presented in the following outline. The remainder of this document builds upon the outline, providing additional detail on such topics as preliminary planning, legal issues, organizational structures, selection of mitigation measures, and historical reviews. Appendix A lists information sources, and Appendix B contains responses to the State Emergency Plan Survey, updated in October 1990.

As a planning tool, the outline serves four functions:

1. It provides an overview of procedures which may be follow'ed in developing a plan. A time sequence or set of priorities is not implied by the organization of the outline, though the planning process necessarily requires that some steps be undertaken before others. Some steps may be taken concurrently, and others may be omitted.

2. It presents detailed suggestions of what might be included in the plan itself, thus combining process and content in one outline.

3. It suggests a format for organizing the plan's contents, emphasizing a management plan (Sections $I I I$ and VI) and a fuel-specific and measure-specific response plan (Sections IV and V).

4. It serves as an internal review mechanism by which a state that already has a plan can check its comprehensiveness and viability, leading to revisions or improvements.

\footnotetext{
'The current document is a revision of Nancy E. Collins' and John H. Sorensen's Preliminary Considerations for State Energy Emergency' Planning, prepared for the U.S. Department of Energy (DOE), by Oak Ridge National Laboratory (ORNL), ORNL/TM-7876, I982. A variety of information sources were used in developing that document. Twenty-one state planning documents were reviewed for their strengths, weaknesses. organization, and contents. Many individuals and groups were consulted, including ORNL staff, public interest groups, federal agency personnel. and represe'ntatives from state governments. Their revien's and comments were reflected in the original document and in this update. The update was prepared by Barbara H. Hardy of Indiana University and David I. Bjornstad of ORNL. It draws heavily from the original decument, but also presents a good deal of new information. The authors wish to recognize the valuable comments and guidance provided by the DOE Gifice of Energy Emergencies throughout the preparation of this document. The authors and the DOE Office of Energy Emergencies wish to thank the 1990 State Seminar Host States-Nen Hampshire. Lowisiana, Missonri, and Califormia-for providing l'aluable revien's of the document.
} 


\section{Outline for State Energy Emergency Planning}

\section{Pre-Plan Background Information and Review}
A. Legislative review
B. Planning review
C. Historical review

II. Management Responsibilities and ORganization
A. Normal (nonemergency) management tasks
B. Emergency management tasks
C. Organizational structure

III. ENeRgy Emergency Plan Management AND Support Elements
A. Planning purposes, goals, and objectives
B. Planning context
C. Management coordination and communication
D. Public information program
E. Data collection and monitoring system
F. Data analysis and reporting

IV. Energy-Solíce Specific Mitigation Measures
A. Measure descriptors
B. Measure-specific legal authority
C. Measure-specific implementation details
D. Energy conservation predictions
E. Impact assessment

V. Planning and Management of Measure-Generated Crises
A. Identification of potential crises
B. Crisis mitigation
C. Essential services

\section{PoSt-EMERGENCY ASSESSMENT}

A. Emergency review and response assessment

B. Plan revision 
As this outline indicates, the planning process may be broadly divided into six steps. These steps may serve as a checklist for the needed actions prior to developing, implementing, and evaluating an energy emergency plan.

I. CONDUCT A PRE-PLAN REVIEW OF BACKGROUND INFORMATION THAT WILL INCLUDE EXISTING LEGISLATION AND POTENTIAL CONFLICTS, A REVIEW OF EXISTING EMERGENCY PLANS OF OWN AND OTHER STATES, AND A REVIEW OF PAST EMERGENCIES AND THE RESPONSE TO THOSE EMERGENCIES.

II. CLEARLY DEFINE THE LINES OF AUTHORITY, MANAGEMENT, AND ORGANIZATION FOR BOTH EMERGENCY AND NON-EMERGENCY SITUATIONS.

III. DELINEATE IN DETAIL THE GOALS OF THE PLAN, WHEN THE PLAN IS TO BE USED, THE COORDINATION REQUIRED OF MANAGEMENT AND COMMUNICATION (BOTH INTER- AND INTRA-AGENCY AND PUBLIC INFORMATION), AND SUPPORT ELEMENTS OF THE PLAN.

IV. ONCE THE DECISION HAS BEEN MADE AS TO WHICH FUELS WILL BE ADDRESSED IN THE EMERGENCY PLAN, MEASURES NEED TO BE IDENTIFIED, EVALUATED, AND SELECTED FOR MINIMIZING THE IMPACTS (BOTH ECONOMIC AND SOCIOECONOMIC) AND MAXIMIZING THE ENERGY SAVINGS FOR ANTICIPATED LEVELS OF SHORTAGES.

V. CREATE DETAILED PLANS FOR MITIGATION OF NEGATIVE SOCIOECONOMIC IMPACTS, INCLUDING IDENTIFYING THE TECHNIQUES AND RESOURCES TO BE USED. ALSO, IDENTIFY AND PRIORITIZE THOSE SERVICES ESSENTIAL TO MAINTAINING PUBLIC WELL-BEING.

VI. AFTER IMPLEMENTATION OF THE PLAN, PREPARE A CAREFUL STUDY ASSESSING THE STRENGTHS AND WEAKNESSES OF THE PLAN'S IMPLEMENTATION. THIS ASSESSMENT SHOULD ALSO BE CONDUCTED AFTER AN EMERGENCY.

Use this page as a reminder, keeping these six steps in mind when developing your plan. 


\section{Pre-Plan Background Information and RevieW}

Prior to the development of an emergency plan, it is desirable to undertake a variety of information-generating tasks that will assist state officials in selecting planning options. The extent of these activities will depend largely on the level of resources available to state energy and emergency management agencies. A thorough understanding of past and existing energy circumstances, related implementation plans, and legal authorities contributes to the development of an energy emergency plan that is workable and effective.

A. Legislative Review. Federal and state legislation, rules, and regulations determine the limits of a workable plan. How an energy emergency relates to such legislation and policies should be assessed by the state attorney general's office or by the state energy office's legal counsel. Requirements for new legislation should be identified as soon as possible. A review can cover the following topics at appropriate levels of detail.

1. Federal Legislation. The development of a national energy policy is manifested through legislation beginning in the early 1970s and through the 1980s. Executive Order 11490 and, more recently, Executive Order 12656 assign the energy emergency preparedness function to U.S. Department of Energy (DOE); in 1981 the DOE's Office of Energy Emergencies (OEE) was created in response to the initial order. Two of the most important pieces of legislation are the Emergency Policy and Conservation Act of 1979 (EPCA) and the Energy Emergency Preparedness Act of 1982 (EEPA). Some issues that might be examined are (1) the implications of these acts for state energy planning efforts, (2) requirements of past federal legislation, and (3) how these relate to each other. It is important that plans relate to the overall context of the federal government's energy policy, reflecting current federal policy in two ways. First, they should complement and make full use of federal programs but should not be dependent on them. Second, plans may cover emergency strategies that are not part of federal programs.

2. Existing State Legislation. Whether specific measures can be enforced and the degree to which a state can effective!y administer its plan in an emergency depend entirely upon the existence and interpretation of the state's legal authorities (legislation, rules and regulations, executive orders, proclamations). Often, the authority will relate to nonenergy emergencies such as natural disasters or civil defense. This review will include identifying the legal actions that all involved agencies may take in specific emergencies, such as a public utility commission's authority during a fuel shortage. Mentioned below is the necessity of legislation protecting proprietary information gained through state-industry contacts.

3. Legal Precedents. A review of court decisions, interpretations of relevant state legislation, and ernergency executive orders are means of identifying strengths and weaknesses in the existing legal structure. In most cases the precedents will not be clearly defined.

4. Legal Barriers. Past emergencies can and may have highlighted legal barriers to implementation of measures that either have not been resolved or, alternatively, have resulted in the enactment of new legislation. These barriers should be identified, and if possible, they should be removed. 
5. Anticipated Liabilities. Scenarios could be utilized to identify situations in which actions called for in a plan might result in claims for damages against the state or its executive officers. Relevant state statutes, regulations, and precedents should be consulted. A detailed and clear understanding of the legal issues will be extremely valuable in an actual emergency.

B. Planning Review. A thorough assessment of existing state plans relating to energy emergency planning can help officials adopt a response plan that best fits the state's needs. Sufficient materials, plans, documents, publications, and data exist to warrant the use of a state's planning time to review these items for transferable contents, examples of organization, and obvious omissions.

1. Existing Emergency Plans. These include natural disaster plans, civil defense plans, energy office organization plans, state energy plans, and EPCA/Energy Emergency Conservation Act of 1979 (EECA) plans. All should be compatible. It is also likely that a great deal of effort has gone into developing planning guides, background materials, and resources for managing a wide range of emergencies. These can be of considerable benefit in plan development.

2. Other States' Plans. Several states, particularly those with high vulnerability to energy shortages, have already invested considerable time and money in developing energy emergency plans. While no single plan can be transferred in its entirety from one state to another, certain philosophies, approaches, or contents may be of use in plan development, maintenance, and revision. This method is especially relevant where commonalities of climate, energy usage patterns, or organizational and political patterns exist. The sharing of such resources, knowledge, and information will save some states both time and money.

C. Historical Review. A plan that is geared to state-specific energy situations, problems, and past emergencies will be more effective.

1. Past Energy Emergencies. Identification of past emergencies and their causes, their economic and social damages, and the responses of the state will aid in determining how the plan's measures can mitigate future emergencies.

2. Fuel Supply and Demand Patterns. Those areas or regions where potential emergencies could exist because of supply-demand patterns, as well as areas of high vulnerability, should be identified.

3. Fuel Import and Export Patterns. Maps and flow charts of fuel movements will aid in assessing the area of vulnerability, and assist in the development of strategies to address any potential vulnerabilities. 


\section{Management ReSPONSIBILITIES ANd ORganization}

Energy Emergency managemeni ncludes a large number of administrative and functional tasks. Clearly defined lines of authority and ieadership are required in both emergency and normal situations; these need to be identified prior to actual development of the plan.

A. Normal (Nonemergency) Management Tasks. Many activities relevant to emergency situations are performed on an ongoing basis. All should be identified and placed within the existing organizational structure so that expansion in an emergency situation can occur with a minimum of disruption. Strong pre-emergency planning will enhance emergency response capabilities.

1. Plan Development. The lead responsibility for development and coordination of the energy emergency plan should be delegated by the governor of the state so that involvement of all relevant agencies will occur. This also includes assessment of personnel and financial resources.

2. Plan Maintenance and Revision. Because of the constant changes in this country's energy situation, responsibility should be specified for ensuring that the plan remains current and that its contents and responses reflect effective means of dealing with an emergency. Also desirable are provisions for revising a plan after the president declares an energy emergency, to make the plan reflective of the particular nature of the emergency.

3. Monitoring. Crises often arise without advance warning. Continuous monitoring of the state's normal energy situation is necessary for providing a baseline against which to measure the impacts of sudden emergencies and to provide early warning of an impending energy emergency. Regional cooperation among states and coordination with federal data-monitoring efforts will facilitate this activity. Assign liaison responsibilities among state staff, federal, and industry representatives.

4. Public Information. In an emergency, the existing energy conservation public information programs and accompanying communication networks may need to be expanded to deter rumors, to perpetuate public support and confidence, and to encourage voluntary compliance with state recommendations. Spokespersons should be identified in advance.

5. Technical Assistance. Throughout the state's organizational structure are agencies, offices, and individuals responsible for providing and utilizing training programs, technical information, workshops, and other subject-specific technical assistance on a regular basis. The identification of such programs will assist in further development of an emergency communication network.

6. Essential Services. State agencies and offices that are responsible for overseeing, administering, distributing, or regulating essential services at both state and local levels should be identified and included in the long-term planning process. 
7. Local Coordination. Those offices and individuals responsible for developing, implementing, enforcing, and monitoring local or regional plans should be included in the organizational framework and communication network with clearly identified roles to play.

8. Readiness Assurance. In planning for other types of emergencies, it is valuable to conduct training and test the response plan and organization. Energy emergency simulations may be patterned after other types of disaster exercises and should include carefully designed monitoring and evaluation components.

B. Energy Emergency Management Tasks. Task areas; identified for nonemergency management (Section II.A) could be expanded or transferred to other organizational entities in order to ranage an emergency efficiently. Additional tasks may be needed, requiring assignment to appropriate agencies.

1. Plan Activation. One individual (e.g., the governor) is usually designated as holding authority for setting the plan in motion; others may be delegated by this individual as having responsibilities for implementing the plan itself. These distinctions should be clear to all involved. Criteria for declaring an emergency should be specified.

2. Coordination and Communication. All entities identified as having tasks during the energy emergency should be aware of each other and have acknowledged means of communicating with each other. Key players should participate in planning exercises and remain in contact during nonemergency periods. Such a formally sanctioned network should clarify roles, improve coordination, and facilitate verbal communications with industry officials and the news media.

3. Monitoring and Data Analysis. During an emergency, daily monitoring, collection, and analysis of data about the changing fuel situation and results of implementing the plan's measures will require constant attention, perhaps shifting or expanding the nonemergency functions of monitoring.

4. Public Information Program. It is likely that the public information efforts required in an emergency will be expanded beyond or altered from those used during normal operations (e.g., greater use of mass media, installation of a hotline and press center). These efforts probably should remain the responsibility of the same person or agency.

5. Measure Implementation. Each measure may be implemented by a different agency, although one agency may have overall responsibility with a variety of others accountable for enforcement (see Section IV). The successful implemen'ation of measures will require a detailed measure-specific plan outlining responsibilities of all relevant parties.

6. Impact Assessment. Monitoring social, economic, and environmental impacts should be the responsibility of one individual or agency so that scope, depth, and interrelationships of impacts may be observed systematically. Impact assessment, however, may require a diversity of expertise and personnel.

7. Measure-Generated Crisis Identification. Responsibility for dealing with hardships created by government actions should be considered along with impact assessment. 
8. Measure-Generated Crisis Mitigation. Identifying specific methods for reducing these crises may be the responsibility of one or more agencies at state or local levels. This responsibility includes implementing, enforcing, and monitoring the response efforts.

9. Plan Deactivation. It will also be necessary to assign responsibility for determining when the emergency is over and how emergency actions are to be phased out. Again, specified criteria will aid in this determination.

10. Post-Emergency Assessment. The likely candidate for managing this task is the agency responsible for developing the plan, although the assessment itself could be produced by a task force representing all the agencies involved in carrying out an emergency plan.

C. Organizational Structure. Once tasks and responsibilities have been defined, it is desirable to formally outline or chart both the normal and the emergency management structures. An examination of existing emergency response structure should aid in this task.

1. Lead Organization. Emergency response efforts work best when one person or organization is clearly in charge. There is no single agency or position that can be specified for this role, and it will differ among states.

2. Support Organizations. Because of the broad and complex nature of energy emergencies, the organizational structure should include all government, public, and private organizations that may play roles in the response effort. In every case it will be vital to coordinate emergency responses with energy suppliers in the private and quasi-public sectors of the economy.

3. New Organizations. Response capabilities in some cases can be enhanced by the creation of a new organization to deal with the problem. While the organization would not necessarily have agency status, a special committee or section of an existing agency could be established on a temporary basis.

4. Hierarchy of Responsibility. A chain of command with backup capabilities for both normal and emergency conditions will clarify responsibilities and assist in communication and coordination efforts. 


\section{Energy Emergency Plan Management and Suppor't Elements}

A variety of management and support efforts and activities is essential to ensure an effective response. Some of these elements were identified through the process described in Sections I and II, and summarizing management organization and responsibilities as the first phase of planning may be appropriate. Later phases will require examination in greater depth as an integral part of the planning process and as a means of defining the scope of the plan.

A. Planning Purposes, Goals, and Objectives. Ideally, planning officials will articulate goals relating to long-term and short-term energy shortages. Some possible goals include preventing shortages, increasing reserves, reducing negative impacts, distributing the impacts in an equitable fashion, or avoiding economic disruptions.

B. Planning Context. A good plan is the product of an interactive process that involves input from many actors. It should define critical terms and establish the scope of emergencies to be covered. All of the basic concepts then must be related to criteria by which levels of emergency can be measured. Internal and public review procedures assure interaction during the plan's development.

1. Definition of an Emergency. Determining when an energy demand and supply situation becomes an emergency requires a working definition of emergency conditions and impacts. based partially on the language of relevant legislation.

2. Scope of Emergencies. A wide range of emergencies can occur with respect to each fuel. It is essential to define those to which the state may be vulnerable, and which are most probable, even though a planning agency may be faced with limited resources. Oil interruptions are the most likely situation considered; however, other tuel emergencies, such as those resulting from natural disasters, should also be considered.

3. Magnitude of the Emergency. Some criteria need to be established to measure the severity and level of an emergency and the magnitude of resulting negative impacts. Other state plans, federal guidelines, and past emergencies provide suggestions for appropriate definitions.

4. Public Review and Comment. Many states find it appropriate to call for public review of plans and actions taken, particularly when proposed measures are mandatory.

C. Management Coordination and Communication. A functioning network linking agencies and agency representatives with each other is essential during implementation of all stages of the plan: normal situation, emergency, and post-emergency assessment.

1. Information-Sharing Responsibilities. individuals should be designated within each agency as having responsibility for receiving and distributing messages and information within the network. Certain channels might be specified for use in an emergency so that loss of valuable time is kept to a minimum. 
2. Managemınt Information Needs. Certain types of data. information, and reports will be required in an emergency situation. These should be specified in the plan, along with their sources and a schedule for relaying such needed information throughout the network.

3. Technical Assistance. Information on technical aspects of implementing specific measures, training sessions for new or temporary staff members, workshops to encourage voluntary compliance, and other support functions will come from all agencies but need to be coordinated by the lead agency. Duplication of efforts, both in administration and in geographical coverage, can be avoided by coordinating these efforts through the communication network.

D. Public Infor:nation Pıogram. Most state energy offices already have public information programs designed to reach specific classes of users with a range of information and services. It will be necessary in an emergency to rely heavily on the program to keep the public inforned about the magnitude of the situation, to let them know what actions are expected or requested of them, and to tell them what the state is doing to alleviate the situation. This might require expansion of the normal program and, with advan e preparation, red :se the lead time for implementation to a minimum.

1. Advance Preparation. Jissemination of information to the public via mass media is the primary task of the public information program in an emergency. This process can be accelerated by pre-emergency actions such as establishing news media contacts, obtaining commitments for space and air time. developing scripts and slides for public service announcements, and retaining professionals who can prepare camera-ready copy, posters, and pamphlets on a few days ' notice.

2. Public Response. The public information program should be the focal point for receiving complaints, answering questions, and handling problems encountered by the public during the emergency. A telephone hotline may be established solely for this purpose, or an existing hotline may be promoted for use by the public. Either way, implementation details (equipment, promotional literai'ure, standby staff) should be completed prior to an actual emergency.

3. Coordination. The public information program is closely related to the management communication network and to the technical assistance tasks. Coordination among involved agencies is essential to present an image of unity and competency to the public.

\section{E. Data Collection and Monitoring System.}

1. Existing Capabilities. Each state should conduct a review of its ongoing energy information capabilities, both business-as-usual and emergency, including but not limited to (a) fuel-specific data on production. distribution systems, receipts by the state, sales to other states, and inventory: (b) Jata on energy consumption by fuel and by sector; (c) frequency of reporting; (d) accuracy, timeliness, and format of aggregated data; and (e) capacity of utility companies and the sectorial distribution of their customers.

2. Minimum arf Ideal Requirements. Each state should determine its data needs for (a) the ongoing monitoring of energy supply and disposition for use in short-term forecasting models, (b) the determination of energy emergency indicators for identifying impending shorages and response capabilities, and (c) special monitoring procedures to be used with increased frequency during energy emergencies for the assessment of the impacts of mitigation measures. 
3. Data Collection System. A system that meets at least the minimal needs of the state should be designed, drawing on federal, state, and private (e.g., trade association) data systems. Provisions must be made for special monitoring procedures during periods of energy emergencies. If the state is to make use of proprietary data from industry, it must be able to assure protection of the data and should make the neressary provisions. Statistical sampling techniques that save money and time should be given serious consideration whenever feasible. The state should draw on existing data collection efforts at the state level, supplemented by available information from sources such as Energy Information Administration (EIA) publications (see Appendix).

4. System Development and Operation. Budget and staffing details should be prepared, and a detailed work plan for the system 's operation should be developed. Special operating procedures during emergencies must be devised and tested.

\section{F. Data Analysis and Reporting.}

1. Guidelines for Data Analysis. A program should be developed for data inalysis during both nonemergency and emergency periods. States may wish to identify short-term forecasting models for ongoing use. Energy emergency indicators should be identified, and procedures for calculating them should be developed.

2. Procedures for Impact Assessment. These would include general methodologies for utilizing available data to project the impacts of likely energy emergency scenarios under a variety of voluntary and mandatory mitigation measures.

3. Reporting System. Serial data should be published, distributed in a timely fashion, and made available to officials. Similarly, appropriate methods should be developed for the prompt dissemination of the results of data analyses. States should anticipate and be prepared to respond to requests for state-specitic information from the Governor, other state agencies, other states, and DOE. 


\section{Energy Source-Specific Mitigation Measures}

Once the decision has been made as to which forms of energy will be addressed in the emergency plan, measures need to be identified, evaluated, and selected for minimizing the impacts and maximizing the energy savings for anticipated levels of shortages. Under appropriate conditions it may be desirable to combine measures or to implement measures in a sequence according to the severity of the shortfall. Listed in this section are specific aspects that may be addressed for each measure, assuming that measures are grouped by fuel.

A. Measure Descriptors. The definition and limitations of each measure must be set forth clearly and without ambiguity for all involved in planning, implementing, or complying with the measure.

1. Name. The same name or title of a measure should be used throughout the plan. Also, it should accurately reflect the purpose of the measure and should be simple enough for use in public information efforts.

2. Description. A working definition will establish the boundaries of the measure as imposed by the plan and limited by circumstance.

3. Femptions. The arialysis of essential services (II.A.6) should have identified priority institutions and specific classes of users which, by virtue of their unique needs, should be exempt from certain measures. Naming exemptions at this point will ease the public review process later and possibly will reduce the number of complaint cases in an actual emergency.

4. Equity. Measures should distribute the impacts so as to avoid disproportionate burdens on individual groups of end users; therefore, any measures that leave room for doubt as to their fairness must be proven reasonable in their restrictions, keeping the preference for market forces.

5. Voluntary and Mandatory Nature. Several aspects of a measure (e.g., exemptions, equity, legal constraints, and enforcement) need to be addressed only if the measure is mandatory. Clearly, the implementation procedures for a measure differ considerably depending on whether it is voluntary or mandatory. Furthermore, the nature of some measures is likely to change from voluntary to mandatory as the shortage worsens and/or the impact of the shortage worsens. Presentation in a matrix format of the nature of each measure as it changes with the situation (see Section III.B.3) is useful as a summary table. Specific details can be given in the discussion for each measure.

B. Measure-Specific Legal Authority. By reviewing the legal aspects related to each measure prior to actual implementation, difficulties may be anticipated or disposed of in a prudent and satisfactory manner. Of course, the analyses conducted during the pre-planning phase (see Section I.A.) form the basis for identifying legislation pertinent to each measure. 
1. Existing Legislation. Some measures, particularly those of a voluntary nature, may be covered by specific enabling legislation; others may be covered under the powers of the governor authorized in a disaster or an energy emergency.

2. Coordination and Communication. All entities identified as having tasks during the energy emergency should be aware of each other and have acknowledged means of communicating with each other. Such a formally sanctioned network should clarify roles, improve coordination, and facilitate verbal communications with industry officials and the news media.

3. Legal Constraints. Any inconsistencies of the measure with policies, laws, or regulations at the local, state, or federal level should be identified.

4. Required Legal Authority. Inconsistencies may be handled in two ways: (a) develop appropriate legislation or other legal authorization, including a delegation of authority under EECA; or (b) alter the measure to conform with legal and constitutional requirements.

C. Measure-Specific Implementation Details. The best plan in the world may fail without the staff, time, money, and designated implementation procedures to carry it out. It is effective and useful to present, in tabular form, a summary of these elements for each measure.

1. Responsibilities. The level, degree, and authority of each agency (both primary and supporting) are defined at this point. based on pre-planning information (Section II) and the management plan (Section III).

2. Lead Time. "Best estimates" concerning the length of time required to establish effective operation of the measure in case of an emergency will contribute to evaluation and selection of the measure.

3. Costs and Funding. Anticipated costs of implementing and maintaining each measure, as well as expected funding sources and required staffing needs, should be presented. States should expect to fund their own programs.

4. Staffing Requirements. Personnel needec to administer, enforce, and monitor each measure within the various agencies should be presented in terms of existing staff, new hires, or temporary staff additions required during the emergency.

5. Enforcement Procedures. A mandatory measure must be enforced by a designated agency (e.g., local police, state troopers) at the appropriate administrative level. Fines associated with this enforcement must be within legal limits.

6. Implementation Barriers. Any of the preceding measure-specific elements might produce a barrier to implementing the measure. If not already resolved, these barriers should be summarized, and ways to eliminate them should be described.

7. Public Information Needs. Each measure requires certain public information efforts to encourage voluntary compliance or explain mandatory enforcement. If these efforts fit into the public information program or go beyond it (see Section II.C), an explanation should be provided. 
D. Energy Conservation Predictions. Each measure should be assessed in terms of expected energy savings and in relation to target savings that may have been established by state or federal authorities.

1. Estimated Energy Savings. The amount of energy conserved by each measure should be presented and compared to agreed-upon baseline data. It should also be presentied as a percentage figure so that it can be related to the percentage of shortfall expected in the specific emergency situation.

2. Calculations and Methodologies. An acceptable and valid means for estimating energy savings should be applied to each measure, including actual calculations and sources of data used. Alternative methodologies should be evaluated and the one best suited for the state's use selected. Aspects of several methods may be combined to produce a tailor-made computational technique. It may be that no existing methodologies are appropriate, in which case development of a new technique is required.

3. Estimated Compliance. The percentage of the target population expected to comply with a measure is an important factor in calculating the energy savings and should be specified.

E. Impact Assessment. Both the emergency and the emergency mitigation measures may produce negative socioeconomic impacts. The plan needs to identify possible impacts, apply appropriate assessment methods, and specify how the impacts will be measured.

1. Impacts on Economic, Social, and Environmental Systems. Prior to an emergency, a complete identification of potential impacts arising from various types of emergencies and mitigation measures should be made.

2. Assessment Methods. A number of options that are available to assess the nature of environmental, economic, and social impacts. These should be reviewed to determine their appropriateness and refined to fit the specific needs of state government.

3. Impact Indicators. A final set of quantitative indicators should be developed or selected to measure the magnitude of the various impacts. Mechanisms and specified methodologies for collecting data on these indicators should be specified. 


\section{Planning and Management of Measure-Generated Crises}

Implementation of certain emergency measures may lead to hardships and losses for some people. The impact assessment (Section IV.E) is intended to reveal specific problems. Steps may then be taken to soften those impacts and to avert disruption or breakdown within the society.

A. Identification of Measure-Generated Crises. People can absorb a certain amount of negative impacts without undue hardship, but at some point either the magnitude or cumulative effect of impacts may cause more widespread crisis conditions. At that point, heightened action is warranted. A first step, however, is to define and identify conditions that would warrant mitigation or crisis response. Procedures then could be established to determine when the level of impacts reaches a critical level.

B. Crisis Mitigation. Planning efforts would include identification of steps that may be taken to relieve some of the hardships created by emergency measures. For example, if people who live in one area or members of a particular group such as the elderly are experiencing disproportionate difficulties in coping with the measures, provisions to alleviate those difficulties should be made.

1. Techniques. Strategies and tactics for reducing the hardships of an emergency should be identified, including evaluation of the nature of the action, the type of hardship to be alleviated, and any associated socioeconomic costs.

2. Resources. An assessment of available resources for crisis mitigation is recommended prior to an emergency. For example, such action might rely heavily on existing public and private disaster services.

3. Implementation. Procedures to implement the various crisis mitigation techniques alsc require formal definition (Section IV.C).

C. Essential Services. Essential services are those activities and functions in the public and private sectors that are vital to maintaining public well-being, health, and safety. Familiar examples are hospitals, police protection, waste disposal, and communication systems. Since most of these are managed at the local level, it is here that contacts with local agencies assume the greatest importance. In an energy emergency, it will be necessary to ensure that essential services are maintained at an adequate level.

1. Identification of Essential Services. Each state must identify which functions are essential to the public well-being. Officials at the service locations should be contacted and included in development of this portion of the plan.

2. Priorities. Criteria for setting priorities should be developed and applied to establish a ranking of essential services. Coordination with privately operated services and local government is essential. 
3. Establish a Curtailment Schedule. A system should be established to curtail services in order to conserve energy. This system will depend on the priorities that are established by the state and the severity of the emergency.

4. Energy Savings and Impacts. During the emergency it will be important to assess the trade-offs between energy savings and socioeconomic costs associated with interruptions. Guidelines for modifying policies concerning cutbacks and restoration of services should allow flexibility and be responsive to the emergency.

D. Mixed Incentives for Suppliers. Although states have responsibilities for the provision of essential services, actions to allocate fuels or energy services or to control prices may be met with resistance by energy suppliers. In the worst case such actions could lead to discrimination against a state by the interstate suppliers. States can avoid these impacts by establishing criteria for essential services provisions well in advance, avoiding arbitrary market intervention, and by maintaining close communication with suppliers concerning state energy emergency planning.

E. Industry Outreach. Provisions should be made to involve industry, either on an ad hoc or other basis, in identifying and planning for emergencies. A liaison representative to industry should be established and publicized to industry.

F. State-Industry Coordination. It should be decided well in advance what the level of coordination will be between the state and industry in terms of the planning process, the crisis identification stage and cooperation during an actual emergency. 


\section{Post-Emergency Assessment}

Following any emergency, a careful study should be conducted to assess the strengths and weaknesses of responses. A truly comprehensive plan should provide for a post-emergency study.

A. The Emergency Review. A diverse group representing state and local governments, universities, private industries, and public interest groups should analyze the recent emergency and recommend changes in planning policy as necessary. Changes should be made on the basis of a detailed account of the causes of the emergency, the fuel supply and demand patterns, and the resultant socioeconomic impacts. Assessment concerns that should receive special attention are records detailing the mitigation actions, measurement of the public response, and evaluation of the effectiveness of actions taken.

B. Plan Revision. As a result of the post-emergency study, it will be possible to evaluate the adequacy of existing energy emergency plans and revise them to eliminate deficiencies revealed in light of the actual experience. 


\section{APPENDix A}

\section{INFORMATION SOURCES}




\section{INFORMATION SOURCES}

The following are reports on various subjects published by the Department of Energy's (DOE's) Energy Information Agency (EIA)':

State Energy Price and Expenditure Report 1987, DOE/EIA-0376(87).

Energy prices and expenditures based on the consumption values estimated in the State Energy Data Report 1960-1987.

Petroleum Supply Monthly, DOE/EIA-0109.

Production of crude oil, refinery and bulk terminal stocks of selected petroleum products, and iriports of residual fuel by sulfur content.

Petroleum Supply Annual, Volume 1, DOE/EIA-0340/1.

Annual data on production of crude oil, refinery and bulk terminal stocks of selected petroleum products; imports of residual fuels for states of entry by sulfur content; number and capacities of operable refineries; working storage and shell storage capacities at refineries and gasoline blending plants; and shut down, new, and reactivated refineries.

Petroleum Supply Annual, Volume 2, DOE/ElA-0340/2.

Data series as in Volume 1 shown by month for production of crude oil, refinery and bulk terminal stocks of selected petroleum products; and imports of residual fuel for states of entry by sulfur content.

Petroleum Marketing Monthly, DOE/EIA-0380.

Refiner/reseller sales prices and volumes for leaded and unleaded regular, premium, and average motor gasoline by type of seller; refiner sales prices and volumes to end users and for resale of aviation gasoline, kerosene-type jet fuel, propane (consumer grade), kerosene, No. 1 distillate, and No. 2 distillate; sales prices of No. 2 fuel oil for selected states by type of seller and end user; sales prices of No. 2 fuel oil for selected states by end user; refiner/reseller prices of residual fuel for selected states by sulfur content; volumes of first sales for consumption of motor gasoline by grades, aviation gasoline, kerosene-type jet fuel, propane, and distillate fuel oils.

Petroleum Marketing Annual, DOE/EIA-0487.

Annual and monthly data for refiner/reseller sales prices and volumes for leaded and unleaded regular, premium. average, and total gasoline by type of seller; refiner sales prices and volumes to end users and for resale of aviation gasoline, kerosene- and naphtha-type jet fuels, propane (consumer grade) kerosene, No. 1 distillate, and No. 2 distillate for selected states by type of seller and end user; sales prices of No. 2 fuel oil for selected states by end user: refiner/reseller prices of residual cuel for selected states by sulfur content; volumes of first sales for consumption of motor gasoline by grades, aviation gasoline, kerosene-type jet fuel, propane, and distillate fuel oils. Appendices inciude sales and deliveries of distillate fuel oil, residual fuel oil, and kerosene by end use.

U.S. Crude Oil. Natural Gas, and Natural Gas Liquids Reserves, DOE/EIA-0126. (Annual)

Estimated crude oil proved reserves and indicated additional reserves, reserves changes and production: estimated total natural gas, nonassociated natural gas, associated-dissolved natural gas, dry natural gas, and natural gas liquids proved reserves, reserves changes, and production; estimated natural gas plant liquids and lease condensate proved reserves and production.

Natural Gas Monthly DOE/EIA-(0130.

Marketed production of natural gas; well determination filings; activities of underground storage operators; deliveries and average prices to residential, commercial, industrial, electric utility, and all consumers; and city gate prices.

\footnotetext{
'Source: State Energy Data Report 1960-1988. Energy Information Administration.
} 
Natural Gas Anmual, Volume I, DOE/EIA-0131/1.

Natural gas production, transmission, and consumption balance table; gross withdrawals and marketed production; offshore withdrawals; number of producing wells; estimated proved reserves; reported wellhead value and imputed marketed value; volume and average price purchased from producers; interstate movements and movements across U.S. borders; injections to and withdrawals from storage; underground storage capacity; natural gas processed; liquids extracted; estimated extraction loss: supplemental gas supplies; consumption of natural gas, numbers of consumers, quantity, value, and heat content of natural gas delivered to consuming sectors; average city gate price; average price and heat content price of natural gas delivered to consuming sectors; summary statistics for each State.

Natural Gas Annual, Volume II, DOE/EIA-0131/2.

Data for 1967 forward for gross withdrawals and marketed production; number of producing wells; average wellhead price and imputed marketed value; interstate movements and movements across U.S. borders; injections to and withdrawals from storage; supplemental gas supplies 1980 forward; production, transmission, and consumption balance table; consumption of natural gas, number of consumers, quantity, and heat content of total natural gas delivered; average price and heat content price of natural gas delivered to consuming sectors; and average consumption and annual cost per consumer in the residential, commercial, and industrial sectors.

Gas Supplies of Interstate Natural Gas Pipeline Companies, DOE/EIA-0529.

Estimates of 1987 demonstrated reserve base of coal type and mining method.

Weekly Coal Production, DOE/EIA-0218.

Bituminous coal and lignite and anthracite production, by week, month, and year-to-date.

Coal Distribution, (Quarterly), DOE/EIA-0125.

Distribution of coal to State of destination and consuming sectors by district of origin and method of transportation.

Quarterly Coal Report, DOE/EIA-(0121.

Coal production; receipts, consumption, and stocks by end-use sector; coke plant receipts, production, and stocks; and coal production trends.

Coal Production, DOE/ElA-0118 (Annual).

Coal production and number of mines by type of mining, and mine production range; bituminous, subbituminous, lignite, and anthracite production by coal group; production by coal rank, minebed thickness, and type of mining; production and average mine price by type of mining, disposition, and coal rank; underground and surface mining productivity: average number of miners working daily by type of mining; recoverable coal reserves and average recovery percentage by type of mining; average daily production, daily productive capacity, and percent utilization; stocks; and demonstrated reserves base by rank and potential method of mining.

Electric Power Monthly, DOE/EIA-0226.

Net generation by energy source, consumption of fossil fuels by type of fuel, coal and petroleum stocks, receipts and average cost of coal by type, petroleum products by type and sulfur content, and gas by type for steam-electric plants with capacity of 50-megawatts or larger, sales of electricity to consuming sectors.

Electric Power Annual, DOE/EIA-0348.

Number of electricity generators and generating capability, by fuel source and by type of generating unit; net generation by type of generating unit and by energy source; consumption and receipts of fossil fuels; stocks of coal and petroleum; average cost of fossil fuel receipts; sales of electricity and average number of consumers by end-use sector; revenue from sales and average retail prices by consuming sector; sulfur dioxide, nitrogen oxides, and carbon dioxide emissions by type of fossil fuel; and number and capacity of generators with environmental equipment by type of equipment. Appendices contain planned capability additions by energy source. 
Cost and Quality of Fuels for Electric Utility Plants Annual, DOE/ElA-0191.

Data for steam-electric plants with a capacity of 50 megawatts or larger; receipts of coal and average cost by sulfur content: origin and destination of coal receipts; receipts by type of coal; petroleum receipts by product type; gas receipts by type of gas; fossil fuels purchase data in Btu; average cost of coal reczipts by type of purchase and product, and of gas receipts by type of purchase: coal and petroleum receipts and average cost by sulfur content and type of purchase: and origin and destination of coal receipts including quality and cost data.

Inventory of Power Plants in the United States, DOE/EIA-0095 (Annual).

Number of generating units, operable capacity, and planned capacity additions by energy source.

Electric Sales, Reve'nue, and Bills, DOE/EIA-0540 (Annual).

Electric sales, revenues, and number of consumers by sector and by utility class of ownership; and average revenue per kilowatt-hour by sector and b. utility class of ownership. Includes monthly bills by type of consumer and level of consumption for electric utilities within states.

Nuclear Power Plant Construction Activity, DOE/EIA-(0473 (Annual).

Nuclear power unit information grouped by State (no State totals).

Uranium Industry Anmual, DOE/EIA-0478.

Reasonably assured resources by forward-cost category; economic resources in tons of ore and pounds of uranium concentrate: uranium concentrate production, and employment in the uranium industry.

Solar Collect,r Manufacturing Activity, DOE/EIA-017:; (Annual).

Destinatioit of solar collector shipments and top three states of solar collector manufacturing.

Also available is DIALCOM, an electronic bulletin board sponsored by DOE/OEE. For information, call OEE at (202) 586-1311.

Forms and additional information that the ElA publishes may be obtained by writing

Energy Information Administration

MS BG-094 Forrestal

U.S. Department of Energy

Washington, D.C. 20585

or by calling the National Energy Information Center at (202) 586-8800. 


\section{APPENDIX B}

\section{Responses to The State EnERgy}

Emergency Plan Survey of OCtober 1990 


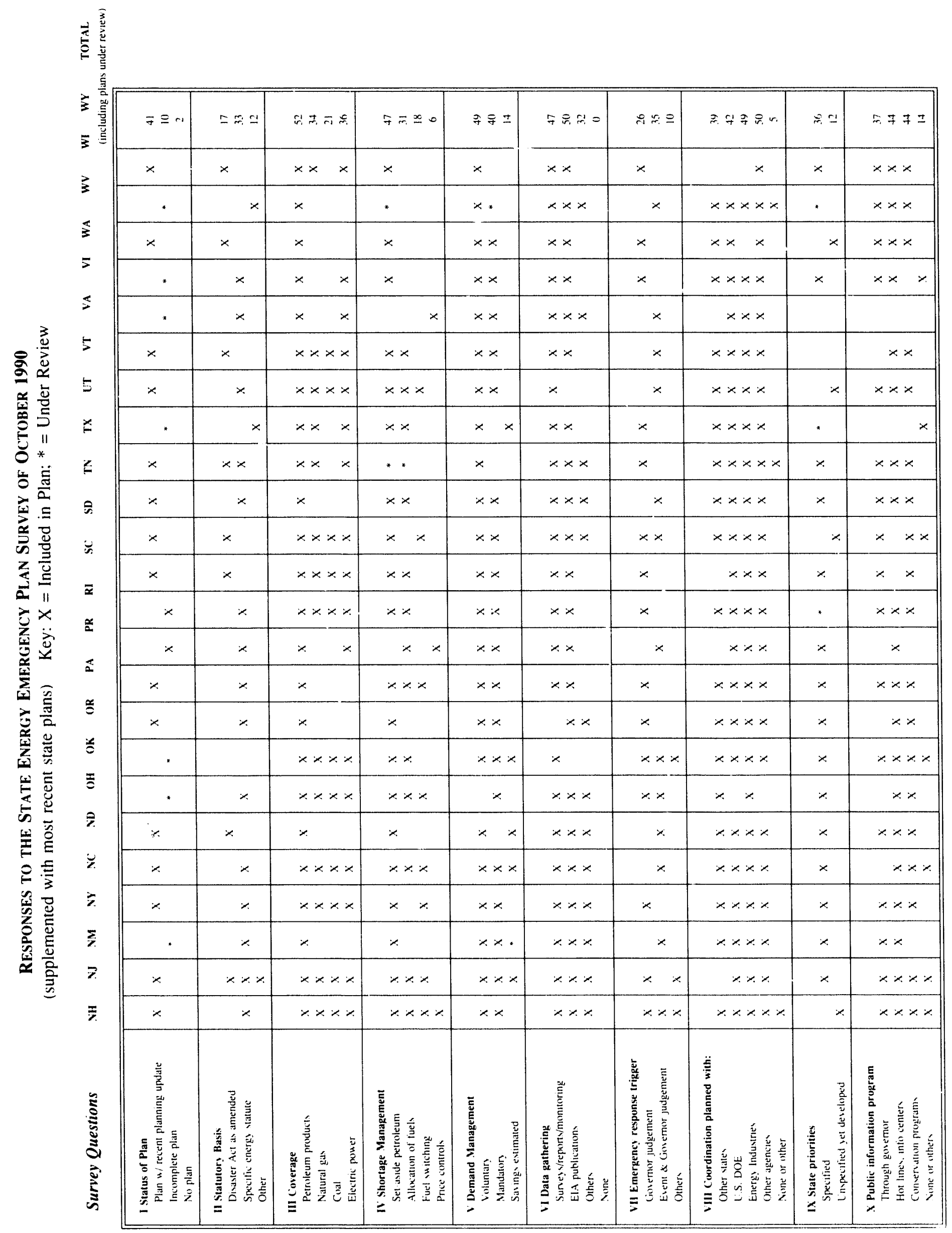




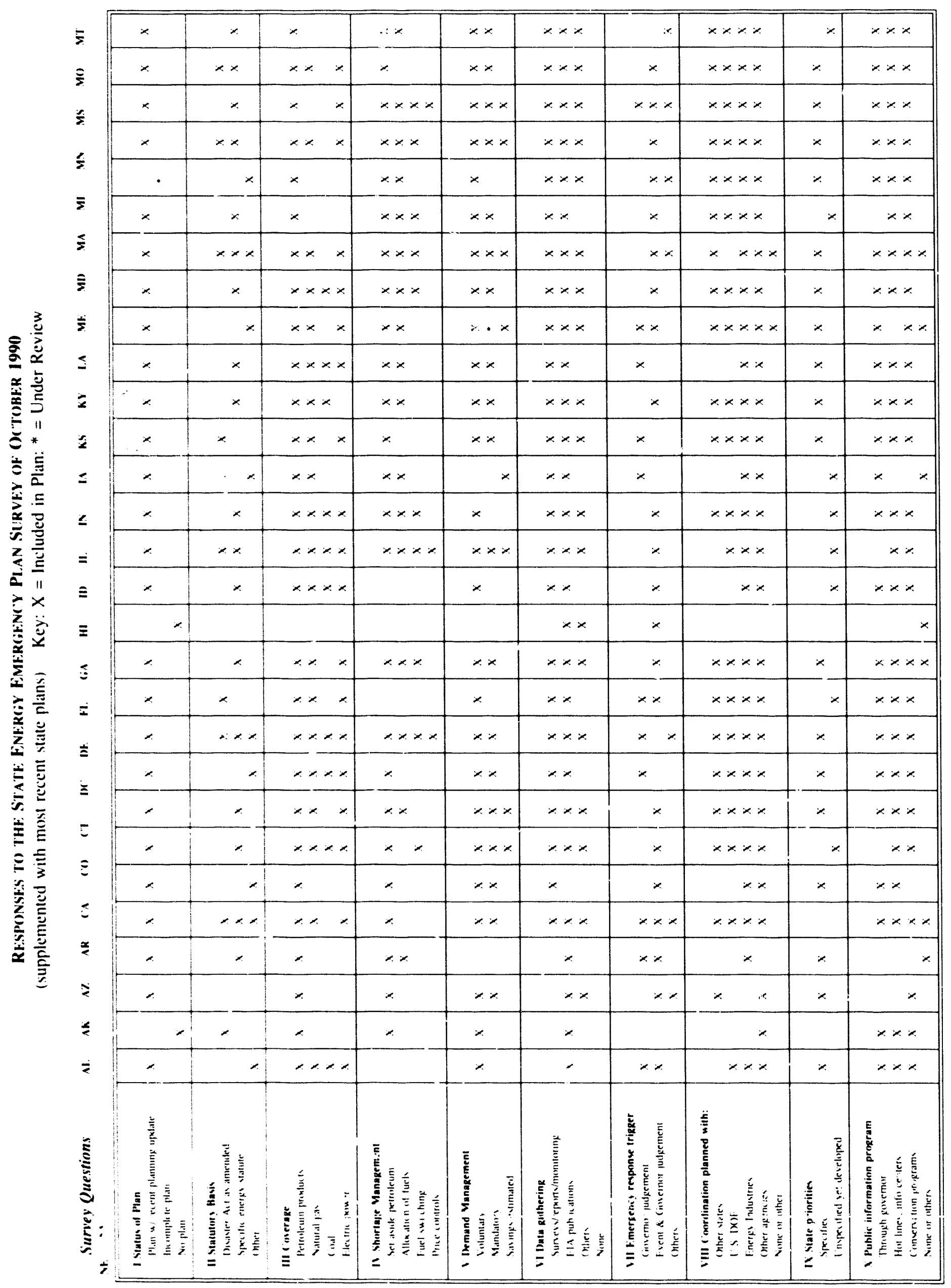




\section{APPENDix C}

ENERGY EMERGENCY AUTHORITIES 


\section{ENERGY EMER(jenCy AUTHORITIES}

This summary is not a complete listing of authorities available to the U.S. Department of Energy (DOE). Rather, those noted are intended to illustrate the range of authorities available when a serious energy emergency exists.

\section{Energy Policy and Conservation Act (EPCA), Pub. L. 94-163 (42 U.S.C. 6201 et seq.), as amended}

This law provides DOE with broad authority to limit exports of energy supplies, including coal, crude oil, petroleum products, natural gas, or petrochemical feedstocks. EPCA further authorizes the President to require increased production of crude oil or natural gas on federal lands and, subject to certain conditions, state lands, during a "severe energy supply interruption." EPCA provides for the creation and management of a Strategic Petroleum Reserve for use in the event of a "severe energy supply interruption" or to fulfill the obligations of the U.S. under the Agreement on an international Energy Program. This act also authorizes the President to require companies subject to the jurisdiction of the U.S. to divert oil supplies to other International Energy Agency (IEA) member countries in satisfaction of U.S. allocation obligations. EPCA also provides for authorities to enact emergency conservation programs for federal government facilities and commercial buildings.

\section{Defense Production Act of 1950 (DPA), Pub. L. $81-774$ (50 U.S.C. App. 2061 et seq.); DPA has lapsed}

DPA authorizes the President to require performance on a priority basis of contracts or orders that he deems "necessary or appropriate to promote the national deferise", and to allocate materials and facilities "in such manner, upon such conditions and to such extent as he shall deem necessary or appropriate to promote the national defense." This act further provides for the ability to maximize domestic energy supplies if the President makes certain findings with respect to the need for the materials or equipment for the exploration, production. refining, transportation, or conservation of energy supplies or for the construction or maintenance of energy facilities.

\section{Natural Gas Act, Pub .L. 75-688 (U.S.C. 717 et seq.)}

This act grants DOE the authority to authorize imports and exports of natural gas and-where the public interest requires-to expedite the processing of an application by waiving its administrative procedures and issuing an emergency interim order authorizing the import or export of natural gas.

\section{Natural (Gas Policy Act of 1978, Pub. L. 95-621 (15 U.S.C. 3301 et seq.)}

This act provides emergency authority to "authorize purchases of natural gas" and to allocate supplies of natural gas" in interstate commerce. Exercise of this authority depends upon the existence or imininence of a "severe natural gas shortage, endangering the supply of natural gas for high-priority users."

\section{Federal Power Act, Pub. L. 66-280 (16 U.S.C. 791a et seq.)}

The Federal Power Act permits DOE to order temporary connections of facilities and such generation. delivery, interchange, transmission or power wheeling of electric energy as in its judgment will best meet the emergency. This act also authorizes the Federal Energy Regulatory Commission to order 
interconnections and wheeling transmission services, if such actions are in the public interest and would promote efficient use of the facilities in question, conserve energy, or improve system reliability.

Public Utilities Regulatory Policies Act of 1978, Pub. L. 95-617 (16 U.S.C. 2601 et seq. and 15 U.S.C. 717z)

Section 607 grants the President authority, following a finding of a "severe natural gas shortage endangering the supply of natural gas for high-priority uses" to prohibit the burning of natural gas by any electric powerplant or major fuel-burning installation. Exercise of this authority requires an emergency finding identical to that in the Natural Gas Policy Act.

\section{Powerplant and Industrial Fuel Use Act, Pub. L. 95-620 (42 U.S.C. 8301 et seq.)}

This act provides authority to allocate coal (and to require the transportation thereof) for the use of any powerplant or major fuel-burning installation. Again, exercise of this authority requires a finding of a severe energy supply interruption as defined in Section 3 (8) of EPCA.

\section{Export Administration Act, Pub. L. 96-72 (50 U.S.C. App. 2401), as amended}

This act authorizes the President to "prohibit or curtail the export of any goods" in order, inter alia, to further the foreign policy interests of the U.S., to protect the economy from a drain of scarce resources, or to obtain leverage against countries that aid terrorists, to carry out the policies of the act. This act restricts exports of crude oil transported in the Trans-Alaska pipeline (Alaska North Slope crude oil). It further specifies that the export restrictions imposed by the act or by other provisions of law do not apply to exports of oil to any country pursuant to a bilateral international oil supply agreement entered into by the U.S. before 1979, or to any country pursuant to the IEP oil-sharing system.

\section{Disaster Relief Act of 1974, Pub. L. 93-288 (42 U.S.C. 5121 et seq.)}

Upon finding that an emergency or major disaster exists pursuant to 42 U.S.C. 5141, the president may direct any federal agency to utilize its available resources and personnel in support of state and local disaster assistance efforts. 

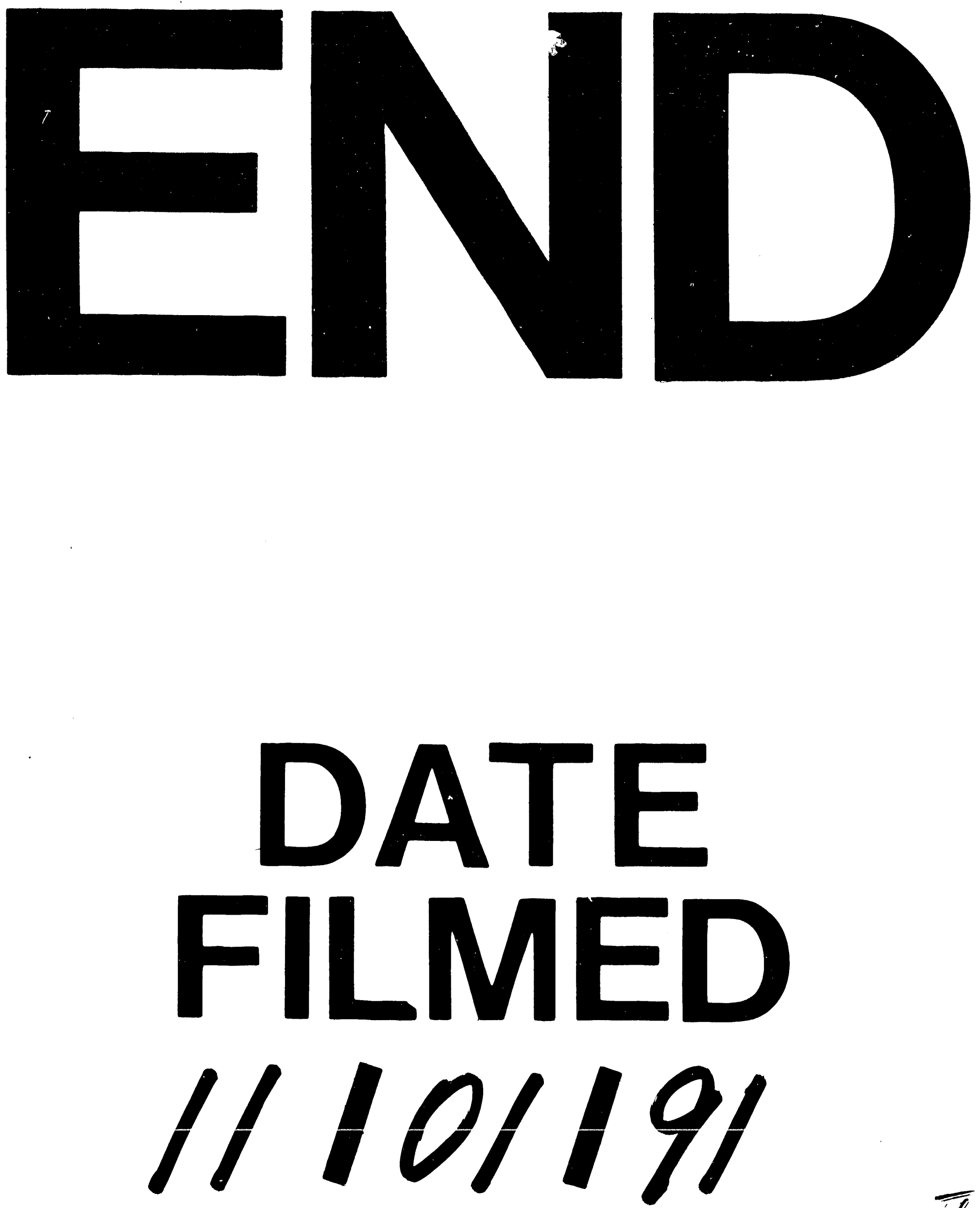

$\bar{I}$ 
